\title{
Effect of Labor, Technology and Experience on Productivity of Rubber Smallholders in Kabupaten Banyuasin With Training as Moderating Variables
}

\author{
Yahya Yahya ${ }^{1, *}$ M. Yusuf ${ }^{1}$, Elisa Elisa $^{1}$, Yusnizal Firdaus $^{1}$, AlHushori AlHushori $^{1}$, \\ Suyatno Ladigi ${ }^{2}$, Dafa Aulia ${ }^{3}$, Tarisa Tarisa ${ }^{3}$ \\ ${ }^{1}$ Department of Business Administration, Sriwijaya State Polytechnic, Indonesia \\ ${ }^{2}$ Sosial Sains Gunaan, Universiti Sultan Zainal Abidin, Terengganu, Malaysia \\ ${ }^{3}$ Student of Department of Business Administration, Sriwijaya State Polytechnic, Indonesia \\ ${ }^{*}$ Corresponding author. Email: yahya.alkaf@polsri.ac.id
}

\begin{abstract}
This study is aiming to analyze the simultaneous and partial effect of labor, technology, farming experience, training and labor interaction and training on the productivity of rubber farmers in Banyuasin regency. Using primary data, the population is all rubber farmers. The number of samples as many as 100 farmers, the determination of the sample by the method of proportionate stratified random sampling. The data analysis technique is multiple linear regression with moderating variables. Based on the results of the analysis, it was found that simultaneously the variables of labor, technology, farming experience, training and labor interaction and training had an effect on farmer productivity. Partially the variables of labor, technology and farming experience have a positive and significant effect on farmer productivity, while partially training does not have a positive and significant effect on farmer productivity. Training is a moderating variable for the influence of labor on the productivity of rubber farmers in Banyuasin Regency.
\end{abstract}

Keywords: Labor, Technology, Farming Experience, Productivity

\section{INTRODUCTION}

The agricultural sector is the main source of income for rural communities in Indonesia. Common problems faced by rural communities such as the quality of human resources, the ability to transform technology and capital, of course have a very close relationship with the emergence of various problems in the agricultural sector (Kharisma, 2017). In addition, the distance between villages and cities is the cause of the difficulty in selling agricultural products. Management of agricultural land in Indonesia is divided into two types, they are large plantations owned by private companies and StateOwned Enterprises (BUMN) and small plantations owned by small farmers which are dominated by smallholder agricultural land. According to data from the Central Statistics Agency or BPS (2020), it was noted that the main plantation sectors such as rubber, cocoa, palm oil, cloves and tobacco contributed to supporting GDP even during the COVID-19 pandemic where the value of plantation exports as of October 2020 was 395.5 trillion rupiah or an increase. by 11.6 percent from 2019 of 322.1 Trillion Rupiah. These data indicate that the opportunity to increase income from the export sector of the plantation sector has the opportunity to continue to be increased, one of which is by giving serious attention to rubber plantations.

Rubber plantation is one of the agricultural sectors that produces rubber latex or known as latex. Around 70 percent of rubber plantations in Indonesia are dominated by small household rubber plantations or better known as community rubber plantations, and the remaining 30 percent are private plantations and State-Owned Enterprises (BPS, 2020). In an effort to increase the export yield of latex, various efforts need to be put in place, one of which is by spurring an increase in latex production from Rubber Smallholders.

The Rubber Smallholders in Banyuasin Regency is one of the largest smallholder plantations in Indonesia. Natural resources that are very supportive make rubber plantations a source of income for the majority of people in Banyuasin Regency. Based on data from the Central Statistics Agency of Banyuasin Regency (2020), the area of Rubber Smallholders in Banyuasin Regency has increased where in 2018 it was $92,890 \mathrm{Ha}$ with a total production of 100,281 tons, in 2019 it was $101,641 \mathrm{Ha}$ with a total production of 103,024 tons and in 2020 an 
area of 101,641 Ha with total production 103,594 tons. The production of Rubber Smallholders is 55 percent of the total production of rubber plantations in Banyuasin Regency, the remaining 45 percent is produced by large plantations. This is certainly very contradictory where the area of Rubber Smallholders which is more dominant should be able to produce more latex production than large plantations.

\section{LITERATURE REVIEW AND HYPOTESIS DEVELOPMENT}

In farming activities, every farmer, of course, really expects the profit of his farming which is very dependent on the production process (Mariyah, et al., 2018). The process is of course a process that is carried out in a sustainable manner by optimizing human resources in quality and quantity and the utilization of available natural resources (Ary, et al., 2017). Ability to utilize quality resources such as understanding of agricultural technology and work experience, while utilization in quantity is to utilize the number of workers. Utilization of human resources must be based on the principle of efficient and effective empowerment, the purpose of which is an assessment of the productivity of farmers in increasing production. Increasing plantation production can of course improve the welfare of smallholder rubber farmers as well as increase regional income which in turn becomes the basis of national economic strength. According to Tri and Setiawina (2016), the agricultural and plantation sectors are the basis of the strength of the rural economy where the majority of the population in rural areas depend on agriculture and plantations for their livelihoods. The contribution of agriculture and plantations is a major contributor to national income and is economically sustainable in achieving economic growth.

The land area which is still very large should be able to increase agricultural production with agricultural intensification (Dika and Widanta, 2017). One of the problems in managing agricultural land is the limited ability of farmers to work on the land, so they have to hire other people. This can be avoided by using family members' time to help work on the farm. The number of family members is an asset of human resources that can be optimized to create cost efficiency of production. The increase in production depends on how much the targeted production changes and the availability of production factors owned such as capital, labor (human resources), the amount of natural wealth and the level of technology used (Sukirno, 2015). The Solow Model uses elements of population growth, capital accumulation, technological progress (exogenous), and the amount of output that interacts with each other. In addition, Solow uses a production function model that allows substitution between capital. $(\mathrm{K})$ and labor $(\mathrm{L})$. The growth rate comes from three sources: capital accumulation, increased labor supply and technological progress. This technology can be seen from the increase in skills or technical progress so that productivity increases. Labor efficiency reflects people's knowledge of production methods. Labor efficiency increases when technology advances, developments in health, education or workforce skills are available (Mankiw, et al., 2013). Thus it can be said that the outpouring of working time by household workers and technology plays a very important role in production.

According to Fachrista (2014), human resources (farmers) play an important role in all aspects, including the agricultural sector because the use of other production factors such as capital, natural resource processing and technology depends on the ability of farmers which implies the ability to be productive, manage and utilize technology. Agriculture which is basically progress in the agricultural sector in an effort to increase agricultural productivity can be realized if it is able to make changes in the mindset of farmers from traditional to the latest technology. According to Ariessi and Utama (2017), the availability of human resources has a positive and significant effect on farmer productivity, every increase in the number of workers will increase farmer productivity assuming other variables are constant. For this reason, the outpouring of labor time from the family is very meaningful in increasing productivity, which depends on the area of land being managed. The use of family labor will also help create efficiency rather than having to pay for hired labor outside of family labor. Baruwadi (2006) suggests that the allocation of working time is an outpouring of working time by farmers and their families in productive activities for both lowland rice farming and other activities, namely farming other than lowland rice, horticultural crop farming, animal husbandry, farm labor, and other activities outside the agricultural sector. . The need for labor and effectiveness in land area management depends on the allocation of land area and working hours so that the existing workforce in the household can be effectively empowered by choosing to work at home or work outside in an effort to help household income.

Agricultural productivity is also strongly influenced by other production factors, namely technology. Technology is a change in the existing production function in technical production. In addition, technology is a driving factor of the production function, because the more modern technology is used, the more results will be achieved with effective and efficient time. Technology has a positive and significant impact on productivity, this means that if the technology used is more modern, productivity will increase. (Panji and Budhi, 2017). The results of research by Dika and Widanta (2017) show that technology has a positive and significant effect on Farmer Productivity. Knowledge of agricultural technology is often difficult for farmers to adopt because of traditional farming patterns and motivation to keep up with changes. The results of research conducted by Chandre and Davit (2015) show that in running a farming business it is necessary to have good farming knowledge by farmers who can accumulate in farming experience and knowledge so that they are able to manage and manage agricultural land well. Farmers who have longer farming experience make farmers better in carrying out production and development activities in the agricultural sector compared to farmers who have shorter farming experience. This means that the longer the experience of farming, the higher the expertise in farming. Farmer's knowledge is also proven to increase agricultural productivity. The results of research by Dika and Widanta (2017) technology has a positive and significant effect on Farmer Productivity. Technology is a change in the existing production 
function in technical production. In addition, technology is a driving factor for the production function, because the more modern technology is used, the more the results achieved in an effective and efficient time. Technology has a positive and significant effect on productivity, this means that if the technology used is more modern, productivity will increase (Panji and Budhi, 2017).

Agricultural productivity can also be influenced by the experience of farmers where the experience of farmers in dealing with various problems such as conditions of unpredictable natural changes. If work experience has increased, productivity will indirectly increase (Sri and Suresmiathi, 2015). The Sembawa Research Institute (2018) stated that rubber trees require a constant high temperature (26-32 degrees Celsius) and a humid environment in order to produce maximum. These natural conditions cause rubber trees to grow well in Sumatra. However, considering the natural conditions that sometimes experience extreme weather where rainfall is longer than expected, it makes rubber plantation owners nervous because it has an impact on the quantity and quality of production. For this reason, experienced farmers can predict and understand what to do when natural conditions change and other problems occur through experience. Research conducted by Artanegara et al (2016) on rubber farmers proves that farming experience shows a positive and significant effect on farmer productivity. This is because the more experience of farming rubber farmers have, the productivity of rubber farmers will increase, because a lot of experience can make people work more effectively and efficiently with the ability to take into account all the possibilities that will be faced and have been trained to make decisions. right when bad things happen. Sjakir et al. (2015) in his research related to the effect of work experience on the productivity of rice farmers, showed that farming experience had a significant and positive effect on rice productivity. Manpower, technology and farming experience in increasing productivity of course must be supported by efforts to achieve it, one of which is through training.

Training is an effective pattern where farmers who are closer to rural life generally have low levels of education. Nyamekye, et al. (2016) suggested that training can create cognitive effects and non-cognitive effects on farmers. Cognitive effects form special knowledge in relation to farming work, while non-cognitive effects are the impact of changes in attitudes and views in farming, especially following changes in agricultural technology. The results of the study by Mulieng et al (2018) also suggest that extension and training programs will change the behavior of farmers who are generally still traditional. For this reason, it is necessary for extension workers who have competence so that they can change farmers' perceptions. Research conducted by Dika and Widanta (2017) shows that training has a positive and significant effect on Farmer Productivity. Training is an effort to develop human resources. Training is also an educational process that aims to remember the special abilities or skills of a person or group of people. Regular education and training will improve abilities and skills and productivity. Training is significantly correlated with farmer productivity (Ibitoye and Onimisi, 2013). The findings of the research of Artanegara, et al. (2016), found that training has a positive and significant effect on farmer productivity, this means that the more training that is obtained regarding an agricultural product, the more it will encourage someone to improve their performance. Research by Fadzim, et al. (2016), in his research using regression which shows a significant positive relationship between efficiency and knowledge. This shows that farmers can be more efficient in farming when they have acquired basic knowledge and skills about agriculture in their farming activities. Based on theoretical studies and several studies, the framework of thinking in this study is as follows:

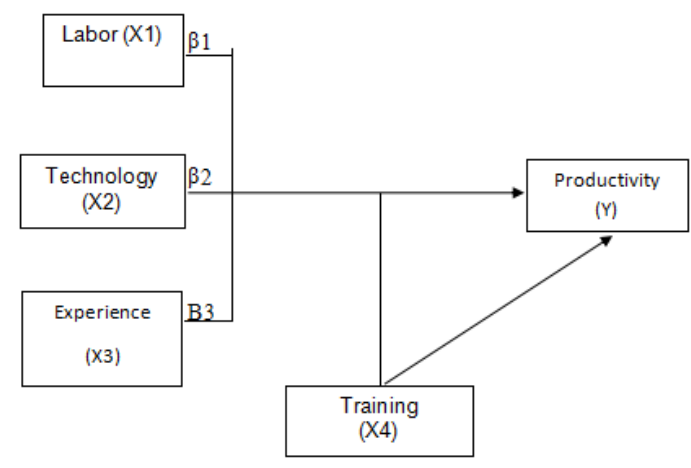

Figure 1 Conceptual Framework

The hypotheses proposed in this study are as follows:

H1: There is a positive and significant effect between technology and productivity of rubber plantations

$\mathrm{H} 2$ : There is a positive and significant effect between experience and productivity of rubber plantations

H3: There is a positive and significant effect between human resources moderated by training on rubber plantation productivity

H4: There is a positive and significant effect between training moderated technology on rubber plantation productivity

H5: There is a positive and significant effect between experience moderated by training on rubber plantation productivity.

\section{RESEARCH METHODOLOGY}

This research is a quantitative study to test the hypothesis on the basis of positive philosophy related to the influence of labor, technology and work experience on the productivity of Rubber Smallholders with training as a moderating variable. The type of research is field research so that data is obtained by distributing questionnaires to smallholder plantation owners. The location of this research is in Banyuasin Regency, South Sumatra Province with the reason that Banyuasin Regency is one of the areas that has the largest rubber plantations in Indonesia and is dominated by smallholders. The variables in this study consisted of 3 variables, namely the independent variable, the dependent variable and the moderating variable. The independent variables consist of human resources (X1), Technology (X2) and work experience (X3). The dependent variable is productivity (Y) and the moderating variable (Z) is training.

The operational definition in this study is Labor (X1) is the number of family workers used in the production process as measured by the outpouring of working time per hour per day. Technology (X2) is the use of technology such as quality seeds, fertilizers, pesticides and so on which are measured by following good management rules or not. Farming experience (X3) as measured by the length of time working as a planter. Training $(\mathrm{Z})$ is an effort to improve the quality of agricultural human resources by looking at participation in the given training program as 
measured by a dummy (have or have not attended training). Productivity (Y) is measured by the amount of production produced in kilograms per hectare unit of measurement. Respondents in this study are homogeneous where the researched is smallholder rubber farmers so that all respondents have the same opportunity and are able to represent to be used as samples. Questionnaires were distributed randomly with accidental technique and obtained 100 respondents. The analysis technique uses multiple linear regression with training variable moderation to see whether it strengthens or weakens the influence between the independent variable and the dependent variable. In multiple linear regression analysis using the general model of the Cobb-Douglas equation:

$\operatorname{LnY}=\alpha+\beta 1 \operatorname{LnX} 1+\beta 2 \operatorname{LnX} 2+\beta 3 \operatorname{LnX} 3+\beta 4 X 4+\beta 5 X 1 X 4+\mu \mathrm{i}$.

Information:

$\mathrm{Y}=$ Productivity $(\mathrm{Kg} / \mathrm{Are})$

$\alpha=$ Intercept (constant)

$\mathrm{X} 1=$ Labor (Hours)

X2 = Technology (Million Rupiah)

$\mathrm{X} 3=$ Farming experience (Years)

X4 = Training (Dummy)(Moderating Variable)

$\beta 1=$ Regression coefficient of labor $(\mathrm{X} 1)$

$\beta 2=$ Regression coefficient of technology $(X 2)$

$\beta 3=$ Regression coefficient of farming experience $(\mathrm{X} 3)$

$\beta 4=$ Regression coefficient of training (X4)

$\beta 5=$ Regression coefficient of interaction of labor $(\mathrm{X} 1)$ and training (X4) on productivity (Y)

$\mu \mathrm{i}=$ Estimated bully error

\section{RESEARCH RESULT AND DISCUSSION}

The characteristics of respondents is a description of the identity of the respondent which will be presented in detail based on age, gender, education level, workforce, technology, farming experience, training and productivity. The age of a person who is engaged in the agricultural business can support his activities in producing quality products. The higher the level of a person's age, the more mature his thoughts will be to improve the quality of the products produced and age can determine the intensity and type of activity that a person can do. Based on the results of the research conducted, it can be seen that the grouping of respondents based on age is shown in Table 1.

Table 1. Distribution of Respondents by Age

\begin{tabular}{|c|c|c|}
\hline Age & Respondent & $\%$ \\
\hline $25-34$ & 20 & 20 \\
$35-44$ & 40 & 40 \\
$45-54$ & 14 & 14 \\
$55-64$ & 18 & 18 \\
$>64$ & 8 & 8 \\
\hline Total & 100 & 100 \\
\hline
\end{tabular}

The table shows that the age of smallholder rubber farmers in Banyuasin Regency is dominated (40\%) aged $35-44$ years which at that age is the productive period of a farmer in general. Although in the productive period, of course, you must know the gender because there are differences between the productive period of men and women.

Table 2 shows that male respondents are 90 percent, while female respondents are 10 percent. This shows that in Banyuasin Regency the majority of farmers are men because in general those who own agricultural land are men as the head of the family while women usually only help or become workers in the farming process.

Table 2. Distribution of Respondents by Gender

\begin{tabular}{|c|c|c|}
\hline Gender & Respondent & $\%$ \\
\hline Male & 90 & 90 \\
Female & 10 & 10 \\
\hline Total & 100 & 100 \\
\hline
\end{tabular}

Source: Data processed, 2020

Looking at the research data in Table 3 and based on the calculation of $\mathrm{HOK}$, it means that the need for labor depends on the area of land owned or in other words the number of multiples of land area owned shows the number of multiples of the number of workers needed.

Table 3. Distribution of Respondents by Land Ownership

\begin{tabular}{|c|c|c|}
\hline Hectarage & Respondent & $\%$ \\
\hline 2 & 34 & 34 \\
3 & 31 & 31 \\
4 & 18 & 18 \\
5 & 10 & 10 \\
6 & 7 & 7 \\
\hline Total & 100 & 100 \\
\hline
\end{tabular}

Source: Data processed, 2020

The productivity of smallholder rubber farmers also depends on the level of education of farmers. More and more farmers themselves, especially in accepting and understanding changes from the latest agricultural technology. Based on the results of the research conducted, it is known (Table 4). The research data in table 4 shows that the majority of farmers have less education than high school.

Farmer education will be a reflection of the ability to use technology effectively including the ability to choose the right technology to be able to produce optimal results. In this study, the technology in question is agricultural technology in the form of fertilizers and chemical drugs used by farmers in caring for their plants so that they can grow healthy and productive. 
Table 4. Distribution of Respondents by Education

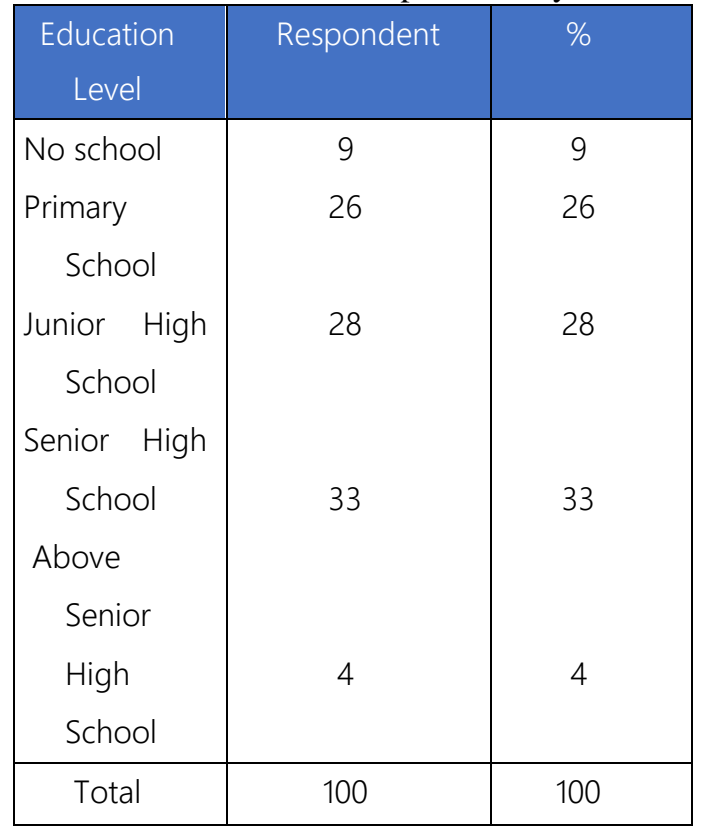

Source: Data processed, 2020

Table 5 shows the amount of use of fertilizers, pesticides, superior seeds and so on in million rupiah. Based on Table 5, it is known that the use of technology in the form of fertilizers, pesticides, superior seeds and so on varies from 4,000,000 more than $6,000,000$ million IDR. The majority of farmers use technology with the rupiah spent ranging from IDR $3,000,001$ to IDR $4,000,000$ i.e., 20 percent and IDR 4,000,001 to IDR $5,000,000$ also 20 percent.

Table 5. Distribution of Respondents Who Allocate Technology Budget

\begin{tabular}{|c|c|c|}
\hline $\begin{array}{c}\text { Technology } \\
(\text { IDR })\end{array}$ & $\begin{array}{c}\text { Respon- } \\
\text { dent }\end{array}$ & $\%$ \\
\hline$\leq 1,000,000$ & 8 & 8 \\
$1,000,001-2,000,000$ & 12 & 12 \\
$2,000,001-3,000,000$ & 15 & 12 \\
$3,000,001-4,000,000$ & 20 & 20 \\
$4,000,001-5,000,000$ & 20 & 20 \\
$5,000,001-6,000,000$ & 13 & 13 \\
$>$ 6,000,000 & 11 & 11 \\
\hline Total & 100 & 100 \\
\hline
\end{tabular}

Source: Data processed, 2020

Farming experience is a real event experienced by farmers by learning from experience that someone will be able to do work faster and better when compared to those who are less experienced so that the output produced will be more and as compensation the income earned is greater. Farming experience is the length of time in working as a farmer expressed in how many years he has been a rubber farmer. Based on Table 6, of the 100 respondents studied, the majority $(25 \%)$ of rubber farmers have 21-25 years of experience.

Table 6. Distribution of Respondents According to Farmer Experience

\begin{tabular}{|c|c|c|}
\hline Technology & $\begin{array}{c}\text { Respon- } \\
\text { dent }\end{array}$ & $\%$ \\
\hline $6-10$ & 8 & 8 \\
$11-15$ & 12 & 12 \\
$16-20$ & 12 & 12 \\
$21-25$ & 16 & 25 \\
$26-30$ & 13 & 16 \\
$31-35$ & 11 & 11 \\
$36-40$ & 3 & \\
$>40$ & 100 & 100 \\
\hline Total
\end{tabular}

Source: Data processed, 2020

Another variable studied in this study is training where it is believed that the productivity of smallholder rubber farmers is strengthened by the training that is followed. The training is of course intended so that farmers can apply technology and can compensate for the lack of experience of farmers by participating in training such as training and counseling in dealing with natural changes, using rubber seeds, technology and management of rubber plantations.

The training in this research is the entire participation of farmers in a training or agricultural extension from related institutions to increase farmers' production and productivity. In this study, training became a dummy variable, namely never (0) and had (1) attended training held by related institutions. Based on Table 7, it can be seen that 45 percent respondents have never attended training, while 55 percent respondents have attended training. Most of the career farmers who have never attended training, it turns out that they can see farmers who have or have attended training and learn on their own to increase latex production, while farmers who have attended their training share the knowledge gained from the trainings they have attended to farmers who have never attended training. participate in training to teach how to increase latex production and deal with changing conditions in nature.

Table 7. Distribution of Respondents by Training

\begin{tabular}{|c|c|c|}
\hline Training & Respondent & $\%$ \\
\hline 0 & 45 & 45 \\
1 & 55 & 55 \\
\hline Total & 100 & 100 \\
\hline
\end{tabular}

Source: Data processed, 2020 
The productivity of Rubber Smallholders in Banyuasin Regency based on research results ranges from $1000 \mathrm{~kg}$ more than $3000 \mathrm{~kg}$ per year (table 8).

Table 8. Distribution of Respondents Based on Rubber Productivity

\begin{tabular}{|c|c|c|}
\hline Training $(\mathrm{kg})$ & Respondent & $\%$ \\
\hline$\leq 1000$ & 15 & 15 \\
$1001-1500$ & 18 & 18 \\
$15001-2000$ & 24 & 24 \\
$2001-2500$ & 33 & 33 \\
$25001-3000$ & 6 & 6 \\
$>3000$ & 4 & 4 \\
\hline Total & 100 & 100 \\
\hline
\end{tabular}

Source: Data processed, 2020

Furthermore, multiple linear regression analysis was performed to determine the effect of the independent variables on the dependent variable. In this study, multiple linear regression analysis with various moderating variables was used to determine the effect of labor, technology and farming experience on farmer productivity with training as the moderating variable.

The results of simultaneous tests were carried out to determine the effect of the variables of labor, technology, farming experience, training and interaction of labor and training on productivity variables using the real level $(\alpha$ $=0.05)$ and degrees of freedom $\mathrm{df}=(6-1) ;(100-6)$. So Ftable with $(\alpha)=0.05$; $\mathrm{df}(5)(94)$ is 2.38 and Fcount is 177.219 , so it can be concluded that the Fcount value is $177.219>$ F-table is 2.39 and the significance value is $0.000<$ from $=5$ percent or 0.05 , then $\mathrm{H} 0$ rejected and H1 accepted, this means that the variables of labor, technology, farming experience, training and interaction of labor and training simultaneously affect the productivity of smallholder rubber farmers. This result is supported by the R Square value of 0.918 or 91.8 percent, which means that 91.8 percent of the variation in the rise and fall of farmer productivity is influenced by variations in the ups and downs of labor, technology, farming experience, training and labor interaction and training, while the rest of 8.2 percent is influenced by other variables that are not included in the research model.

The results of partial testing of the effect of labor on farmer productivity with a significant level $(\alpha=0.05)$ obtained t-table of 1.663 and t-count of 9.321 , so it can be concluded that the tcount value is $9.321>$ ttable is 1.663 and the significance value is $0.000<$ from $=5$ percent or 0.05 , then $\mathrm{H} 0$ is rejected and $\mathrm{H} 1$ is accepted. This means that the labor variable (X1) partially has a positive and significant effect on farmer productivity. The regression coefficient of the workforce (X1) is 0.545 , which means that if the workforce increases by 1 percent, the productivity of rubber farmers will increase by 0.545 percent assuming other independent variables are held constant.

The more the amount of labor used in the production process, the more output is produced (Mankiw, et al., 2013: 46). The results of this study are in line with research conducted by Ariessi and Utama, (2017) partially that labor has a positive and significant effect on farmer productivity. Nyamekye, et al. (2016) who examined corn productivity showed that labor had a positive and significant effect on corn yields.

The results of testing the technology variable partially on the productivity of rubber farmers based on the real level $(\alpha=0.05)$ obtained ttable of 1.663 and tcount of 5.120, so it can be concluded that the value of tcount is 5.120> from ttable of 1.663 and a significance value of $0.000<$ of $=5$ percent or 0.05 , then $\mathrm{H} 0$ is rejected and $\mathrm{H} 1$ is accepted, this means that the technology variable (X2) partially has a positive and significant effect on the productivity of rubber farmers in Banyuasin Regency. The regression coefficient of technology (X2) is 0.160 , which means that if the technology is increased by 1 percent, then the productivity of rubber farmers will increase by 0.160 percent assuming other independent variables are held constant. In terms of the technology used, the more modern the technology used, the more production results achieved in an effective and efficient time.

If farmers adapt farming technology such as using superior seeds, using fertilizers and so on to support production, then this has the opportunity to increase crop yields more than farmers who do not do the same thing (Sukartini and Solihin, 2013). The results of this study are supported by research by Dika and Widanta, (2017) that technology has a positive and significant effect on farmer productivity. The results of research by Sjakir, et al. (2015) shows that the adoption of new agricultural technology has a positive value and significantly affects productivity. Other studies that support the positive and significant influence of technology on productivity is research by Panji and Budhi (2017).

\section{CONCLUSION}

Labor, technology, farming experience, training and interaction between workers and training simultaneously affect the productivity of rubber farmers in Banyuasin Regency. Labor, technology and farming experience partially have a positive and significant effect on the productivity of rubber farmers, while training partially has no positive and significant effect on the productivity of rubber farmers in Banyuasin Regency. Training is a moderating variable for the effect of labor on the productivity of rubber farmers.

For rubber farmers in Banyuasin Regency, although rubber farmers can learn on their own from other farmers, rubber farmers should be able to follow the training provided by the government, where this training aims to provide knowledge about good and correct rubber cultivation so that later rubber farmers can increase their knowledge. and skills and increase the productivity of the 
rubber farmers themselves. For the government or agencies related to the intensity to provide training to farmers, it should be intensified again so that farmers understand and know how to care for rubber plants to grow healthy and well so that the quality of the product and the amount of production can increase so that productivity can increase.

\section{ACKNOWLEDGMENTS}

This research is based on work supported by State Polytechnic of Sriwijaya, Indonesia. The author thankfully acknowledges scientific discussion with our colleagues from State Polytechnic of Sriwijaya, Indonesia. The authors would like to acknowledge the anonymous reviewers at the IC FIRST 2021 for their feedback on an earlier version of the paper, and also thank to the two anonymous reviewers who provided feedback as part of this journal's review process

\section{REFERENCES}

[1] Badan Pusat Statistik, Statistik Indonesia 2019, Jakarta, Indonesia: BPS Pusat, 2020

[2] Badan Pusat Statistik. Banyuasin dalam angka. Kabupaten Banyuasin, Sumatera Selatan, Indonesia: BPS Kabupaten Banyuasin. 2020

[3] Mariyah, Mariyah, Syukat, Yusman, Hartoyo, Sri, Fariyanti, Anna danKrisnamurthi, Bayu. Penentuan Umur Optimal Peremajaan Kelapa Sawit di Kabupaten Paser Kalimantan Timur. Jurnal Ekonomi Kuantitatif Terapan, 11(1), 103-115.

[4] Ary Candra Pramana, I Gede, Murjana Yasa, I Gusti Wayan dan Karmini, Ni Luh. Pengaruh Faktor Ekonomi, Sosial dan Demografi Terhadap Pendidikan Anak Nelayan di Kabupaten Badung. PIRAMIDA Jurnal Kependudukan dan Pengembangan Sumber Daya Manusia, 13(1), 51-58.

[5] Dika Arimbawa, Putu dan Widanta, A.A Bagus Putu. Pengaruh Luas Lahan, Teknologi dan Pelatihan Terhadap Pendapatan Petani Padi Dengan Produktivitas Sebagai Variabel Intervening di Kecamatan Mengwi. E-Jurnal Ekonomi Pembangunan Universitas Udayana, 6(10), 0-0

[6] Sukino, Sadono, Makroekonomi: Teori Pengantar, Edisi ketiga. PT. Rajawali Press. Jakarta, 2015

[7] Mankiw, N Gregory, Eutson Quah and Peter Wilson, Pengantar Ekonomi Mikro Prinsip Ekonomi. Jakarta: Salemba Empat, 2013

[8] Fachrista IA, Sarwendah M, Persepsi dan Tingkat Adopsi Petani Terhadap Inovasi Teknologi Pengelolaan Tanaman Terpadu Padi Sawah, Agriekonomika, 3(1) : 1-10.

[9] Ariessi, Nian Elly dan Suyana Utama, Made, Pengaruh Modal, Tenaga Kerja dan Modal Sosial Terhadap Produktivitas Petani di Kecamatan Sukawati Kabupaten Gianyar. PIRAMIDA Jurnal Kependudukan dan Pengembangan Sumber Daya Manusia, 13(2), 97-107.
[10]Baruwadi, Mahludin, Ekonomi Rumah Tangga, UNG Pres Gorontalo, 2006

[11]Panji Prabawa, A.A. Ngurah dan Kembar Sri Budhi, Made, Pengaruh Modal, Tingkat Upah, dan Teknologi Terhadap Penyerapan Tenaga Kerja dan Produktivitas Pada Industri Sablon di Kota Denpasar. E-Jurnal Ekonomi Pembangunan Universitas Udayana, 6(7), 1157-1184.

[12]Chandre Gowda, M. J. dan Dixit, Sreenath, Influence of Farmers Educational Level on Comprehending, Acting-Upon And Sharing of Agro, 2015

[13]Sri Muliani, Ni Made dan Ayu Suresmiathi, A.A, Pengaruh Pengalaman Kerja Terhadap Produktivitas Pengrajin Untuk Menunjang Pendapatan Pengrajin Ukiran Kayu, E-Jurnal Ekonomi Pembangunan Universitas Udayana, 5(5), 614-630.

[14]Balai Penelitian Sembawa, Saptabina usaha tani karet rakyat. Sembawa, Sumatra Selatan, Indonesia: Pusat Penelitian Karet Balai Penelitian Sembawa. ISBN: 979-529-002.

[15]Artanegara, Made, Djinar Setiawina, Nyoman dan Djayastra, Ketut, Kajian Faktor Sosial Ekonomi yang Mempengaruhi Produktivitas Petani Asparagus di Kecamatan Petang Kabupaten Badung, E-JurnalEkonomi dan Bisnis Universitas Udayana, 5(11), 3741-3764

[16]Sjakir, Muhammad, Awang, Abd Hair, Manaf, Azima Abdul, Hussain, Mohd Yusuf and Ramli, Zaimah, Learning and Technology Adoption Impacts on Farmer's Productivity, Mediterranean Journal of Social Sciences MCSER Publishing, Rome-Italy, 6(4).

[17]Nyamekye, Isaac, Fiankor, Dela-Dem Doe and Ntoni, Jonathan Okyere, Effect of Human capital on Maize Productivity in Ghana: A Quantile Regression Approach, International Journal of Food and Agricultural Economics, 4(2), 125-135.

[18]Mulieng, Zul fikar., Siti Amanah dan Pang S. Asngari, Persepsi Petani terhadap Kompetensi Penyuluh Pertanian Tanaman Pangan di Kabupaten Aceh Utara, Jurnal Penyuluhan, Maret 2018 Vol. 14 No. 1.

[19]Ibitoye, S.J. and Onimisi, J.A, Influence of Training on Farmer's Productivity in Poultry Production nungnung01in Kogi State, Nigeria, International Journal of Poultry Science, 12(4), 239-244.

[20]Fadzim, Wan Roshidah, Aziz, Mukhriz Izraf Azman, Mat, Siti Hadijah Che and Maamor, Selamah, Factors Affecting Efficiency of Smallholder Cocoa Farmers: A Tobit Model Application in Malaysia, International Journal of Economics and Financial Issues, 6(7), 115-119.

[21]Kharisma, Bayu, Pekerja Anak dan Goncangan Pertanian di Indonesia, Jurnal Ekonomi Kuantitatif Terapan, 10(2), 125-136. 